http://dx.doi.org/10.11646/phytotaxa.161.2.11

\title{
On the identity of Lepismium lineare and L. warmingianum (Cactaceae, Rhipsalidae)
}

\author{
JULIO ANTONIO LOMBARDI \\ Universidade Estadual Paulista "Júlio de Mesquita Filho", Instituto de Biociências, Departamento de Botânica, Av. 24A 1515, C.P. \\ 199, 13506-900, Rio Claro, SP, Brazil. \\ Email:cissus@rc.unesp.br
}

\begin{abstract}
Field surveys, cultivation tests and literature examination allowed to clarify the identity and morphological distinction of Lepismium lineare and L. warmingianum. A diagnostic key for the Lepismium species in Brazil is also provided.
\end{abstract}

Key words: Cactaceae, Lepismium lineare, Lepismium warmingianum, taxonomy

\section{Introduction}

Lepismium Pfeiffer (1835: 315) are pendulous epiphytes with flattened or angled to winged branches following a mesotonic (lateral) pattern. They bear white or whitish lateral flowers with angled pericarpel, naked or scaly, and red to purple fruits, when mature (Hunt 2006).

Pfeiffer (1835) originally described three species of Lepismium, L. commune Pfeiff., L. knightii Pfeiff., and $L$. tenue Pfeiff. Since the taxa number of Lepismium was differently considered during time, from one (Britton \& Rose 1923) to 17 species (Backeberg 1959). Morphological studies on the genus included three genera in Lepismium: Acanthorhipsalis Britton \& Rose (1923: 211), Lymanbensonia Kimnach (1984: 101), and Pfeiffera Salm-Dyck (1845: 40), besides a few species of Rhipsalis Gaertner (1788: 137), decreasing the species number to 14 (Barthlott 1987, 1991; Barthlott \& Taylor 1995). Recently, Hunt (2006) and Korotkova (2011) recognized 5, and 6 species respectively, excluding Pfeiffera (including now Acanthorhipsalis and Lymanbensonia) (Hunt, 2006), and Lepismium incachacanum (Cárdenas 1952: 125) Barthlott (1987: 99) that was transferred to the genus Lymanbensonia.

Lepismium warmingianum (Schumann 1890: 291) Barthlott (1987: 99) is considered an heterotypic synonym of L. lineare (Schumann 1890: 296) Barthlott (1991: 89) (Barthlott \& Taylor 1995). However, Lombardi (1995) (sub Rhipsalis linearis K.Schum.) showed morphological differences between L. warmingianum and L. lineare after cultivation. Currently, the most of the authors considered these two names synonyms, following Barthlott \& Taylor (1995).

Cultivation tests on clones of Lepismium lineare (Lombardi 149, 8085 and 8684) and L. warmingianum plants (Lombardi 4065, a clone coming from the Schumann's type locality) were carried out.

The Lepismium lineare clones of Lombardi 149 and 8085, the former after 25 years without producing any flower, bloomed and new interesting morphological data were available and useful to distinguish it from $L$. warmingianum (see below). In particular, the taxa can be easily distinguished by the size of flowers and floral parts, and the occurrence of the rest of the perianth on the young fruits. On the contrary, during the vegetative stage, the two species are very difficult to separate morphologically: although $L$. lineare has branches usually longer, narrower and more profusely branched than $L$. warmingianum, these differences are not observed in all plants, neither in all cultivated individuals. 
Additional specimens examined:-BRAZIL . Minas Gerais: Belo Horizonte, cultivated, cutting from CaldasMG, 5 Oct 2000, Lombardi 4065 (BHCB); Caldas, Oct 1854, Lindberg 611 (BR, MO). São Paulo: Piracicaba, cultivated, cutting from Campinas-SP, 17 Oct 1992, Lombardi 148 (UEC); Rio Claro, Fazenda São José, 15 Nov 2000, Udulutsch \& Assis 85 (HRCB), ibid., 3 Oct 2003, Mania \& Assis s.n. (HRCB 40400, 40635); Rio Claro, cultivated, cutting from Caldas-MG, 2 Sept 2008, Lombardi 7486 (HRCB).

Identification key to Brazilian Lepismium species [L. cruciforme, L. houlletianum (Lemaire 1858: 64) Barthlott (1987: 99), L. lineare, Lepismium lumbricoides (Lemaire 1839: 60) Barthlott (1987: 99), L. warmingianum]

1. Branches terete.

Lepismium lumbricoides

- $\quad$ Branches flattened, angled or winged

2. Flowering areoles sunken, densely hairy, pericarpel not apparent in the flowers after anthesis ........ Lepismium cruciforme

- Flowering areoles not sunken, not hairy or with a few hairs or bristles, pericarpel apparent in the flowers before and after anthesis

3. Branches with a conspicuous, constricted petiole-like base, margin of the flattened blade serrate, with acute teeth

Lepismium houlletianum

- Branches with no conspicuous, constricted petiole-like base, margin of the flattened blade crenate to crenulate, with blunt teeth

4. Flowers $2.5-3 \times 1.5-2.5 \mathrm{~cm}$

Lepismium lineare

- $\quad$ Flowers $1.5-1.8 \times 0.5-1 \mathrm{~cm}$

Lepismium warmingianum

\section{Acknowledgements}

Thanks are due to the Director and Curators of the herbaria cited. Financial support for the current study was provided by CNPq (research grant \#300240/2009-0), and MCT/CNPq/MEC/CAPES/PROTAX (grant \#562240/ 2010-1). I'm grateful to Dr. Duilio Iamonico for the many valuable suggestions that have considerably improved the manuscript.

\section{References}

Backeberg, C. (1959) Die Cactaceae. Handbuch der Kakteenkunde 2. Jena, Gustav Fischer Verlag, 721 pp.

Barthlott, W. (1987) New names in Rhipsalidinae (Cactaceae). Bradleya 5: 97-100.

Barthlott, W. (1991) Lepismium. In Hunt, D.R. \& Taylor, N. (eds.), Notes on miscellaneous genera of Cactaceae. Bradleya 9: 81-92.

Barthlott, W. \& Taylor, N. (1995) Notes towards a monograph of Rhipsalidae (Cactaceae). Bradleya 13: 43-79.

Britton, N.L. \& Rose, J.N. (1923) The Cactaceae 4. Carnegie Institution, Washington, 318 pp.

Cárdenas, M. (1952) Quelques Cactées nouvelles de Bolivie. Cactus (Paris) 7(34): 125-128.

Gaertner, J. (1788) De fructibus et seminibus plantarum 1. Typis Academiae Carolinae, Stuttgart, 516 pp. $+79 \mathrm{pl}$.

Grisebach, A. (1879) Symbolae ad floram argentinam. Abhandlungen der Königlichen Gesellschaft der Wissenschaften zu Göttingen 24: $3-346$.

Hunt, D.R. (2006) The new Cactus lexicon 1, dh Books, Milborne Port, 373 pp.

Kimnach, M.. (1984) Lymanbensonia (Cactaceae), a new genus for Acanthorhipsalis micrantha. Cactus and Succulent Journal 56: $100-101$.

Korotkova, N. (2011) Phylogeny and evolution of the epiphytic Rhipsalideae (Cactaceae), Mathematisch-Naturwissenschaftlichen Fakultät der Rheinischen Friedrich-Wilhelms-Universität, Bonn. Available from: http://hss.ulb.uni-bonn.de/2011/2703/2703.htm (accessed: 19 September 2013).

Lemaire, C. (1839) Cactearum genera nova speciesque novae. J. Loss, Lutetiae Parisiorum, 122 pp.

Lemaire, C. (1858) Rhipsalis houlletiana Nob. L'Illustration Horticole 5(misc.): 64-65.

Lombardi, J.A. (1995) O gênero Rhipsalis Gärtner (Cactaceae), no Estado de São Paulo. II. Espécies com ramos aplanados. Acta botanica brasilica 9: 151-161. http://dx.doi.org/10.1590/s0102-33061995000100008

Miquel, F.A.G. (1838) Plantarum cactearum, in Flora Fluminensi delineatarum, revisio. Bulletin des Sciences Physiques et Naturelles en Néerlande 1: 47-49.

Pfeiffer, L.K.G. (1835) Vorfschlag zu einer neuen natürlichen anordnung der Cacteen. Allgemeine Gartenzeitung 3: 314-315.

Salm-Dyck, J.M.F.A.H.I. (1845) Cacteae in horto dyckensi cultae. Anno 1844. Typis Crapelet, Parisiis, 51 pp. http://dx.doi.org/10.5962/bhl.title.64404

Schumann, K. (1890) Cactaceae. In Martius, C.F.P. (ed.), Flora brasiliensis 4(2). Frid. Fleischer in Comm., pp. 186-322, 1-25 pl. 